\title{
SEVGILI NEDEN SERVI BOYLUDUR?
}

\author{
Metin HAKVERDİĞLU*
}

\section{Öz}

Divan şiiri, sevgili üzerine bina edilmiştir. Bu yüzden sevgilinin her uzvu en ideal olan varlıklara benzetilmiştir. Sevgilinin boyu da bu yüzden ideal fizikî özelliklere sahip olan serviye teşbih edilmiştir. Fakat bu benzetmenin sadece fiziksel yönden olmadığı da bir gerçektir. Divan şairi, hiçbir benzetmeyi tek bir yönü ile kullanmaz. Mutlaka daha derin ve girift ilişkiler arar. Bu ilişkiler uzun gözlemler sonucunda tespit edilir ve sevgilinin bir uzvunu tasvirde kullanılır. İşte servi de bilinen düzgün fiziği yanında pek çok farklı yönleri ile sevgilinin boyu olmayı hak etmiştir. Bu çalışmamızda servinin neden tercih edildiğini maddeler halinde tespit edip bu maddeleri beyitlerle destekleyeceğiz. Örnek beyitleri Lâle Devri kasidelerinden alarak bir dönemin bu mefhumu nasıl kullandığını da göstermeye çalışacağız.

Anahtar Kelimeler: Servi, Divan Şiiri, Sevgilinin Boyu, Lâle Devri, Beyit Açıklamaları.

\begin{abstract}
Has been building on Ottoman poetry is a literary lover. So everything's lover which it has been likened to being the ideal. Because of that the length of the beloved is linked to cypress of the most beautiful physics. But it is also true that the analogy is not just the physical aspects. Ottoman poet uses no analogy with a single direction. Surely it searches deeper and more complex relations. These relationships are determined as a result of long observation and are used to describe the lover of a limb. Behold, cypress, with many different aspects, besides the known physics properly have deserved to be the length of the beloved. In this study, whether identified as the preferred material for reasons that will support the cypress with couplets that stuff. Example couplets, a period of taking the Tulip Period ode we tried to show that this notion of how to use it.
\end{abstract}

Why is Lower Cypress?

\footnotetext{
* Yrd. Doc. Dr., Amasva Üniversitesi Fen Edebiyat Fakültesi, metin.hakverdioglu@amasya.edu.tr.
} 
216 | Metin HAKVERDİOĞLU

Key Words: Cypress, Ottoman Poetry, Length of Lover, Tulip Period, Couplets Descriptions.

\section{Giriş}

Servi, her mevsim yeşil kalması ve boyunun güzelliği ile dikkatleri üzerine çeken bir ağaç türüdür.

Biyolojide bu türün ülkemizde yetişenlerine Cupressus L (servi), C. semper-virens L (âdî servi) adı verilir. "İki evcikli, herdem yeşil ağaç, ağaççıklar." ${ }^{1}$ olarak tanımlanır. "Kuzey Amerika, Akdeniz bölgesi ve Asya'da yayılış gösteren 12 türü vardır. Ülkemizde ise doğal olarak yetişen tek türü bulunur: C. semper-virens L (âdî servi). 20-30 metre kadar boylanabilen, tac kismı piramit veya sütun şeklinde olan ağaçlardır. Mezarlıklarda yetiştirilmeleri nedeniyle ülkemizin pek çok yerinde görülebilir." 2

$\mathrm{Bu}$ ağaç, özellikle su kenarlarında ve mezarlıklarda olması hasebiyle, hem hayatın hem de ölümün sembolü olmuştur.

“Divan şiirinde işlenen ölüm teması genel olarak değerlendirildiğinde; servi motifiyle ilişkilendirilmesi, âşı̆̆ın mezarı ve tabutuyla ilgili isteklerine bağlanır. Gerçek anlamda servi, biyolojik nedenler ve dini inançlardan dolayı mezarlıklara dikilir. Mezarlıklara servi dikilmesinin sebeplerinden biri, onun yaz-kış yeşil kalıp meyvesiz olması özellikleriyle, hayat ağacı olarak nitelendirilmesindendir. Kutsallı̆̆ına inanılan hayat ağacı, Allah'ın sembolü olarak kabul edilir ve ölümden sonra olduğuna inanılan ebedî hayatı simgeler. Ağaçların kötü ruhları temizlediği inancıyla da servi, mezarlıklarda yer alır. Servi ağacının bu özelliği ile Divan şiirinde, âşı̆̆ın öldükten sonra mezarı başında servi istemesi arasında benzetme ilgisi kurulur. Âşı̆̆ın bazen mezarının yanında bazen de mezar taşının yerine servi olmasını istemesinin nedeni, sevgilinin boyunu servide görmesindendir. Öldükten sonra isteklerini anlatan âşı̆̆ın servi ağacından tabuta koyulmasını arzu etmesi, yine sevgilinin boyuyla alakalıdır". ${ }^{3}$

Halkımızın özellikle mezarlıklarda görmeye alışkın olduğu bu ağaç, yüzlerce yıllık divan şiirinde hayatın hemen hemen her alanına

1 Özcan Seçmen ve diğerleri, Tohumlu Bitkiler Sistematiği, Ege Üniversitesi Basımevi, İzmir, 1998, s. 131.

2 Seçmen ve diğerleri, Tohumlu Bitkiler Sistematiği, s. 131.

3 Yunus Kaplan, "Divan Şiirinde Ölüm Karşısında Âşıkların İstekleri”, Turkish StudiesInternational Periodical for the Languages, Literature and History of Turkish or Turkic, c. 5, say1: 3, 2010, s. 304, 305. 
girmiştir. Divan şiirinde avâmın da havâsın da dikkatini çeken bu ağaç, pek çok benzetmenin kaynağ 1 olmuştur. Bu benzetmelerin en bilineni sevgilinin boyudur. Boy; servi yanında; tûbâ, 'ar'ar, nihâl, şimşâd, elif, şem', serkeş, kıyâmet gibi varlıklara da benzetilir.

Bilindiği gibi divan şiirinde her şey bir saray benzetmesi üzerine bina edilir. ${ }^{4}$ Yani padişah daima sevgilidir ve onun kulları da âşıklardır. $\mathrm{Bu}$ benzetmede en değerli varlık tabii ki padişahtır. Ancak bu benzetmede bir dünyaya bakan boyut, bir de ukbaya bakan boyut vardır. Sevgili, gerçekten kalp sarayının sahibi olan bir güzel (sultan) olabildiği gibi, kalbin gerçek sahibi Allah da olmaktadır. Sevgilinin hasletlerini servi ile özdeşleştiren şair, Allah'ın sıfatlarını da bu yolla ortaya koymaktadır.

Agah Sirrı Levend, Divan Edebiyatt-Kelimeler ve Remizler-Mazmunlar ve Mefhumlar adlı eserinde sevgili ve güzellik ilişkisini şöyle tarif etmektedir:

"Sanatkâr güzeli yaratmak ister. Fakat güzellik zamana ve şahsa göre değissen bir mefhumdur. Klasik ressam tek bir modelle kanaat edemez. O mücerret güzelliği yaratmak emelindedir. Güzel ise tabiatta ancak dağınık bir halde bulunur. Hiçbir tek çehre klasik ressamı tatmin edemez. O ister ki yapacağı bir çehre en güzel bir göze, en güzel bir yüze mâlik bir çehre olsun. İşte bu gayretle, muhayyilesinde idealize ettiği güzeli tespit etmeye koyulur. Neticede, her uzvu gerek zamanınca, gerek kendince müstesna güzelliğe sahip olan bir çehreyi tasvir etmiş olur. Fakat bu çehre, hiçbir zaman aynen tabiatta mevcut değildir. İşte divan şairinin tasvir ettiği güzel böyle bir güzeldir." 5

Bu güzelin aynen tasvir edildiği gibi kabullenilmesi, sevgiliyi servi gibi dev bir varlık da yapabilir. Bu yüzden Levend, bu ince noktanın iyi algılanması gereği üzerinde durur ve benzetmelerin derin anlamlarına inilmesi gereğini tespit eder. Serviyi sevgilinin boyu olarak sadece şekli yönünden ele almak onu bir dev haline sokabilir.

Başka bir ağaç yerine servi ağacının sevgili gibi en değerli varlığa boy olarak seçilmesi bu ağaç üzerine tekrar tekrar düşünmemizi gerektirmektedir.

4 Ahmet Hamdi Tanpınar, 19. Asır Türk Edebiyatı Tarihi, Çağlayan Kitabevi, 9. bs., İstanbul, 2001, s. 9.

5 Agah Sirrı Levend, Divan Edebiyatı-Kelimeler ve Remizler-Mazmunlar ve Mefhumlar, Enderun Kitabevi, İstanbul, 1984, s. 490. 


\section{8 | Metin HAKVERDİOĞLU}

Servi ile ilgili aşağıdaki 21 özellik peş peşe sıralandığında divan şairlerinin ne kadar isabetli bir seçim yaptıkları kolayca anlaşılır.

Özerden ${ }^{6}$ tarafından yapılan yüksek lisans tezinde bu konu 15-16. yüzyıl bağlamında ele alınmış ve bu devirde servinin pek çok özelliği beyit beyit tespit edilmiştir.

Bu çalışmada, çeşitli araştırmacılardan ${ }^{7}$ yapılan özet ile servi şöyle tarif edilir:

“Divan şiirinde en çok sözü edilen ağaç çeşidi servidir. Servi, uzun ve düzgün boyludur. Divan şiirinde boyu nedeniyle sevgili, serviye benzetilir. Sevgilinin boyu servi gibi ince ve uzundur. Servi, birçok benzetmede benzetilen olarak kullanılır; bunların en önemlisi ise sevgiliservi-boy ilişkisidir. Kimi zaman sevgilinin boyu ona benzetilirken, servinin sevgilinin boyuna benzetildiği de olur. Çoğunlukla sevgilinin boyu serviden üstün görülür; fakat ikisinin boyunun eş tutulduğu örnekler de vardır. Servinin hafif rüzgârda yavaşça sallanışı da sevgilinin salınışlarını anlatmak için şiirlerde konu olur. Servinin rüzgârdaki bu yavaş hareketi, nazlı oluşuna bağlanır. Hafif ve yavaş salınışlarıyla servi nazlıdır; bu özelliğiyle de sevgiliye benzetilir. Kökü derinde, dalsız bir ağaç olan servi rüzgârda asla eğilmez; sert rüzgârlarda bile eğilmeyip dimdik duruşu, âşı̆̆ın aşk yolunda kararlı ve pes etmeyen tutumunu yansitir"s

Bizim vereceğimiz 18. yüzyıl örnekleri ile servinin bu devirde nasıl yeni çağrışımlar uyandırdığı görülecektir. 860 varaklık Faiz ve Şâkir Mecmuasından taradığımız örnek beyitlerle, divan şairlerinin bu ağacı ne kadar benimsediği bir kez daha ortaya konulmuş olacaktır.

Servinin şu özellikleri dikkat çekmekte ve diğer ağaçlardan onu ayırmaktadır:

1- Servi, düzgün bir boya sahiptir ve doğruluğun sembolü olabilecek ideal bir ağaçtır. Onun yazılışında bile noktalı harf

6 Gülümser Özerden, Divan Şïrinde Servi (15-16. yüzyıllar), Yayınlanmamış Yüksek Lisans Tezi, Çukurova Üniversitesi Sosyal Bilimler Enstitüsü, Adana, 2015.

7 Bkz., Mehmet Çavuşoğlu, Necati Bey Divanının Tahlili, Kitabevi Yayınları, İstanbul, 2001, s. 283, M. Nejat Sefercioğlu, Nev'î Divanının Tahlili, Kültür Bakanlığı Yayınları, Ankara 2001, s. 434, Harun Tolasa, Ahmet Paşa'nın Şiir Dünyası, Akçağ Yayınları, Ankara, 2001, s. 469, İskender Pala, Ansiklopedik Divan Şiiri Sözlüğü, Kapı Yayınları, İstanbul, 2005, s. 400, Yavuz Bayram, "Servi", Türk Dünyası Edebiyat Kavramları ve Terimleri Ansiklopedik Sözlüğü, c. 5, Atatürk Kültür Merkezi Başkanlığı Yayınları, Ankara, 2006, s. 279.

8 Özerden, Divan Şiirinde Servi (15-16. yüzyıllar), s. 4. 
kullanılmaması, onun boyuna kimse ulaşamaz ve nokta koyamaz anlamını taşımaktadır.

2- Servi, her dem yeşil kalması ile İslamiyet'te en sevilen rengi daima taşımaktadır.

3- Servi; boyunun narin, uzun ve hatasız olması ile sevgilinin boyuna benzetilir; ayrıca rüzgârla salınması da sevgilinin salınarak yürümesine benzetilmektedir.

4- Servinin elif harfi gibi düz olması ise Allah'ın birliğine ve doğru yola iletici olduğuna işâret etmektedir.

5- Servi, sevgili olarak düşünüldüğünde dünyevî bir varlık olabildiği gibi Allah da olabilmektedir.

6- Servinin kokusunun güzelliği yine onu diğer ağaçlardan ayırmaktadır. Rahatlatıcı ve dezenfektan olan bu koku, özellikle mezarlıklarda bu ağacı tercih edilir kılmıştır.

7- Servi ağacı, Allah'ın rahmet sıfatını da kendi içinde barındırır. Çünkü yıl boyu yeşil kalan bu ağaç, kuşlar için (özellikle kumrular için) doğal bir sığınak olabilmektedir.

8- Servinin sadık bir sevgilisi vardır: Kumru. Gülün bülbülü, ateşin pervanesi, Leyla'nın Mecnun'u olduğu gibi onun da dünyaca bilinen bir "âşık-1 sâdık"1 vardır. Bu da serviyi diğer ağaçlardan üstün kılmaktadır.

9- Servi, sevgili olduğuna göre serviye yakın olmak da ona kavuşmak olarak yorumlanabilir. Servi, bu bağlamda mezarlıkta bulunması ile de değişik bir îmâya yol açmaktadır: Gerçek servi boylu sevgiliye kavuşmak, ancak servilerin diyarı mezara girmekle mümkündür; yani insan ölünce sevgili Rabbine kavuşur.

10- Yine mezar ve servi ilişkisinde çok kullanılan remiz, servimezar görüntüsünün "âh" ifadesini doğurmasıdır. Elif ile he'den oluşan bu kelimede (oآ) elif, servinin; he ise mezarın sembolüdür.

11- Servinin ilginç bir özelliği de erkek ve dişi hususiyetlerini kendi üzerinde bulundurmasıdır. Yani dışarıdan bir dölleyiciye ihtiyaç duymamasıdır. Mücerret yaşamasıdır, her şeyden âzâde kalabilmesidir. $\mathrm{Bu}$, divan şiirinde sevgilinin cinsiyetsiz olduğunun da bir göstergesidir.

12- Servinin mezarlığa kattığı huzur, onun dağıttığı güzel rayiha, mezar sonrası cenneti müjdelemektedir.

13- Aşırı sağlam ve en uzun ömürlü ağaçlardan olması da onun ayırıcı vasıflarındandır.

14- Sağlam çubuklarından ok yapılır ve bu oklar âşıkların kalbine saplanan gamze için benzetme unsuru olur. 


\section{0 | Metin HAKVERDİOĞLU}

15- Servinin yol boyunca dikilmesi aşırı rüzgârlarda koruyucu olmasının neticesidir. Ayrıca yol boyu bekleyen âşıklara da teşbih edilir.

16- Yaprakların şifalı olan ve rahatlık veren bir bitki olması, adeta "En Sevgili" nin Şâfî ismine telmihtir.

17- Yine rüzgârda eğildiği zaman secde eden bir mümine benzemesi söz konusudur.

18- Servi bazen serkeşlik, yani başı dik olmanın da sembolü olur. Çünkü en dik duran ağaç odur.

19- Servi bereket bekçisidir; dünya bereketine açılan su kenarları, gül bahçeleri veya ahiret bereketine açılan mezar başlarını sever.

20- Bir ilginç durum da servi ağacının dallarının oluşturduğu şekilde gizlidir. Dikkatle bakılırsa (Resim 1) servi ağacının kolları "Allah" lafzının Arap harfleri ile yazılışına benzer. Ana gövdeden hafif kavisli çıkan dallar üçüncü ve en uç kısımda kapanır ve Allah ifadesine benzer bir görüntü verir.

Resim 1

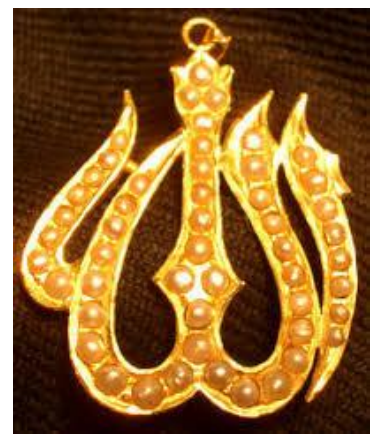

21- Servi salındıkça hayat tekrarlanır durur.

Görüldüğü gibi servinin "sevgilinin boyu" olmayı hak ettiğini gösteren pek çok neden mevcuttur. Divan şairi bu ağacı seçerken sadece dış görünüşünü değil, diğer pek çok özelliğini de dikkate almıştır.

Agah Sırrı Levend, boy bahsinde servi, servi-i çemân, serv-i hırâman, serv- $i$ seĥे tamlamalarını örneklendirmek için, bizim de üzerinde durduğumuz hususlarda şu örnekleri vermektedir:

"Serv kâmetler iki yanın alurlar yolun

Râh-ı gülzâra döner yolları İstanbulun (Bâkî)

(Yol boyunca dizilen güzeller)

Ey kâdi serv-i çemân-i çemen-i gaybü'l-gayb 
Sâyebân eyler idi sâyeni bulsa tûbâ (Nazîm)

(Gölgesi Meşhurdur)

Gör kadd-i yâri serv-i çemân söylerim sana

Bak ol dehâna râz-1 nihân söylerim sana (Nedîm)

(Servi sevgilinin boyudur)

Gamze-i nergis-i mahmurların seyreyle

Cilve-i serv-i sehî-kaddi ser-efrâzına bak (Nef'î)

(Doğruluk-Düzgünlük)" ${ }^{9}$

\section{A- Lâle Devri Kasidelerinde Servi}

Lâle Devri'nin kudretli sadrazamı İbrahim Paşa'ya yazılan kasidelerin büyük bir kısmının bulunduğu Fâiz ve Şâkir Mecmuasından ${ }^{10}$ alacağımız örnek beyitlerle, servinin hangi özellikleri ile bu şiirde yer aldığını ortaya koymaya çalışacağız. Ayrıca diğer dönemlerin büyük şairlerinin meşhur beyitleri ile de konunun daha iyi anlaşılması sağlanacaktır.

Bu mecmuadan beyitlere geçmeden Fuzûlî̀'den meşhur bir servikumru ilişkisi örneği verelim:

\section{1- Servi Dikbaşlıdır}

Fuzulî, servinin serkeşlik (dik başlılık) özelliğini kullanarak âşı̆̆ı olan kumruyu nasıl imtihan ettiğini göstermiştir:

Serv serkeşlük ḳılur ḳumrı niyāzından meger

Dāmenüň țuta ayaġına düşe yalvara șu. ${ }^{11}$

"Servi, kumrunun niyazından yüz çevirmiş, onunla ilgilenmemiş; o zaman su gidip servinin eteğine yapışsın ve âşıkla ilgilenmesi için yalvarsın." Bu beyitte, servi-kumru aşkına çok güzel bir telmihte bulunulmuştur.

Lâle Devri şairi Sa'dî de servinin dik başlılı̆̆ından şikâyet etmektedir:

'Āşıḳa serv gibi ser-keş olan maḥbûbun

Zülfine sünbül-i ter ḳaddine 'ar'ar m1 dinür. ${ }^{12}$

9 Levend, Divan Edebiyatı-Kelimeler ve Remizler-Mazmunlar ve Mefhumlar, s. 491-492.

10 Metin Hakverdioğlu, Damat İbrahim Paşa İçin Yazılan Lâle Devri Kasideleri, Sage Matbaacilik, Ankara, 2012.

11 Kenan Akyüz ve diğerleri, Fuzûlî Divanı, Akçă̆, Ankara, 2000, s. 32.

12 Hakverdioğlu, Damat İbrahim Paşa İçin Yazılan Lâle Devri Kasideleri, s. 471, beyit 6 . 
222 | Metin HAKVERDİĞLU

“Âşı̆̆a servi gibi dik başlılık eden sevgilinin zülfüne sümbül kokulu, boyuna 'ar' ar yani dağ servisi mi denir?"

Lâle Devri'nin meşhur şairlerinden Çelebi-zâde 'Âsım Efendi servinin bahçe duvarlarından dışarı bakar gibi görünmesini, hürlük ve başıboşluk olarak kabul etmektedir:

Eger kim başı țaşra olmasa dîvār-1 gül-şenden

Nice zincîr ururdı cûy-1 pāy-1 serv-i āzāde. ${ }^{13}$

"Eğer servinin başı gül bahçesinin duvarından dışarıda olmasa nasıl o başıboş, serserinin ayağına akarsu zincir vurabilirdi?"

Rahmî Ağa da aynı durumdan bahsetmektedir:

Eger kim pāyını der-bend-i zincîr itmese cûlar

Giderdi bî-tevaḳḳuf servler gül-geşt-i șaḥāya. ${ }^{14}$

"Eğer servilerin ayağına zincir vurmasa akarsular, onlar kesinlikle her zaman ovaya gül bahçesini seyretmeye giderlerdi."

\section{2- Servi Elif-Allah Sembolüdür}

Fuzulî,

Kaçan kim ḳāmetüňden ayrı seyr-i bûstān itdüm

Koparup eşk seylābıyla min servi revān itdüm

derken "serv-i revan" kelimesini iham-1 tenasüple sevgilinin salınmasına işaret ettiriyor; ancak aslında anlattığı şey çok farklıdır:

"Senin boyundan posundan ayrı ne zaman çiçek bahçesine gitsem gözyaşı seli ile bin tane serviyi yerinden koparıp suya veririm. Su onu sürükler götürür."

Bu beytin Ali Nihat Tarlan tarafından şerhi, her ifadeyi yerli yerine koyar: "Kamet, serve benzetilir. (Âşı) sevgilinin vahdetini ifade eden boy posunu düşünmeden, onun âleminde olmadan çiçek bahçesine girince bin tane hakiki serviyi gözyaşı ile yürütüyor. Yani suya verip sürüklüyor. Bir tane hakiki sevgilinin kameti (boyu), bin tane serviden daha üstün(dür); çünkü bu servi çiçek bahçesini süsleyen servidir, maddedir. Vahdet ise sevgilinin (Allah'ın) endamının manasıdır."15

Fuzûlî, burada binlerce dünya güzelini ve güzelliğini; biricik sevgilisi "servi boylusu" Allah için terk edeceğini açıkça ifade etmektedir.

13 Hakverdioğlu, Damat İbrahim Paşa İçin Yazılan Lâle Devri Kasideleri, s. 648, beyit 18.

14 Hakverdioğlu, Damat İbrahim Paşa İçin Yazılan Lâle Devri Kasideleri, s. 746, beyit 13.

15 Ali Nihat Tarlan, Fuzulî Divânı Şerhi, Akçağ, Ankara, 1998 s. 488. 
Servinin elif harfi ile ilişkisini söylemiştik. Elif ile servi, şekli yönünden Allah'ın doğruluğunu ve birliğini ifade eder. Çünkü elif gibi olan servi Allah'ın ve onun varlığının delilidir. Es'ad Çelebi bu konunun bir medresede, tefsir dersinde, kumrular tarafından da ele alındığını söylemektedir:

Serv-i mevzûn üzre ḳumrılar ḳırā'at eyleyüp

'Ārife îmā ile tefsîr-i āyet gösterir. ${ }^{16}$

"Servinin boyu üzerine kumrular sohbet edip ârifâne bir edayla âyet tefsiri yaparlar."

\section{3- Servi Doğruluktur}

Elde tesbîhịi 'ibādetde ḳıyām itmiş çenār

Serv-i bālā istiḳāmet üzre ḳāmet gösterir. ${ }^{17}$

"Çınar, elinde tesbihi ile ibadet için ayağa kalkmış, uzun boylu servi ise yanında dimdik ayakta, boyunu göstermektedir." Sa'dî'nin bu beytinde bir namaz hazırlığı söz konusudur; çınar imam olarak ayağa kalkarken, servi de kamet getirerek doğru yola gelme mesajını, namaza hazırlanma emrini vermektedir.

\section{4- Servi Ferahlık Vericidir}

Hafîd Efendi aşağıdaki beytinde, "Bana serv-i hıramanım temayül gösteriyorken, gölge gibi toprak üstünde rahat ve huzur içinde olsam tuhaf mıdır?" diyerek servinin verdiği ferahlatıcı etkiye de gönderme yapmaktadir:

'Aceb mi sāye-veş fersûde-i hāak-i niyāz olsam

Baña himmet temāyül-güster-i serv-i ḩırāmānım. ${ }^{18}$

\section{5- Servinin Gölgesi Meşhurdur}

Sāye-i serv-i sehîde oturup vaṣf itse

Kadr-i 'ālîsini bir şāa'ir-i sencîde beyān. ${ }^{19}$

Yukarıdaki ferahlık vericiliği destekleyen Rıf'at Çelebi'nin bu beyti de servinin sâyesini yani gölgesini ön plana çıkarmaktadır: "Bir şair, dümdüz servilerin altında oturup o sevgilinin (veya kaside İbrahim Paşa

\footnotetext{
16 Hakverdioğlu, Damat İbrahim Paşa İçin Yazılan Lâle Devri Kasideleri, s. 303, beyit 4.

17 Hakverdioğlu, Damat İbrahim Paşa İçin Yazılan Lâle Devri Kasideleri, s. 263, beyit 14.

18 Hakverdioğlu, Damat İbrahim Paşa İçin Yazılan Lâle Devri Kasideleri, s. 316, beyit 2.

19 Hakverdioğlu, Damat İbrahim Paşa İçin Yazılan Lâle Devri Kasideleri, s. 594, beyit 30.
} 
224 I Metin HAKVERDİOĞLU

için olduğundan İbrahim Paşa'nın) yüce kıymetini vasfetse ne güzel olur."

\section{6- Servi Sevgilinin Boyudur}

Sâhib Efendi aşağıdaki beytinde sevgilinin boyu ile servi arasında bir rekabet olduğunu ve servinin bu konuda sevgiliye yetişemediği için onu kıskandığını belirtmektedir.

Cilve itdikde ḳadüñ șaḥn-1 çemende cānā

Dāmenüñ çîde ider şerm ile serv-i bālā. ${ }^{20}$

“Ey sevgili, çimenlik yerde boyun, posun göründükçe uzun boylu servi kıskançlıkla eteğini toplar durur. Kıskançlıktan çeker gider.

Şerîf de aynı konuya parmak basmaktadır:

Bālā-yı dil-rübā gibi mevzûn u müstaḳ̂m

Bir serve mālik olmadı gül-şende bāg -bān. ${ }^{21}$

"Bahçıvan, (ne kadar istese de) sevgilinin boyu gibi gönül alan, düzgün ve ölçülü bir serviye sahip olamadı."

Kaynak olarak kullandığımız mecmuanın şairlerinden Şâkir Bey, serviyi sevgilinin boyunun yanında çok eksik görmektedir. Sevgilinin boyu ondan çok daha yüksek ve güzeldir.

Kaāmet-i bālā-yı yāre servi teşbîh eyledi

Ṭogrisı ta'bîrde ḩaylîce noḳṣān eyledi. ${ }^{22}$

"(Şairler) serviyi sevgilinin boyuna teşbih ettiler, doğrusu bu tabirle hayli noksan söylediler."

\section{7- Servi Sevgilidir}

15. yüzyılda, meşhur bir beytinde Necati Bey, sevgili ile servinin ilişkisini gösteren aşağıdaki dizeleri lâle, gül, gülşen, gonca, yürüyüş (salınış) gibi tenasüp unsurları ile mükemmel bir gülşen manzarası oluşturmaktadır:

Lâle- hadler yine gül-şende neler itmediler

Servi yürütmediler goncayı söyletmediler. ${ }^{23}$

"Lâle yanaklılar bahçeye girince serviler yürüyemediler. Servi onların boyunun güzelliğini görünce utancından ortaya çııp yürüyemez oldu."

20 Hakverdioğlu, Damat İbrahim Paşa İçin Yazılan Lâle Devri Kasideleri, s. 333, beyit 67.

21 Hakverdioğlu, Damat İbrahim Paşa İçin Yazılan Lâle Devri Kasideleri, s. 351, beyit 27.

22 Hakverdioğlu, Damat İbrahim Paşa İçin Yazılan Lâle Devri Kasideleri, s. 802, beyit 50.

23 Tarlan, Necati Bey Divanı, MEB Yayınları, İstanbul, 1997, s. 268. 
Burada, hüsn-i talil sanatı ile zaten yürümeyen serviyi sevgilinin boyunu gördüğü için yürümeyi unuttu, yürüyemez oldu gibi bir güzel sebebe bağlama söz konusudur. Gonca da normalde konuşmaz; ama hüsn-i talil ile o da "sevgilinin dudağının güzelliğini gördüğü için konuşmayı unutmuş" veya konuşmaktan imtina etmiştir. Kapalı istiare vasitasıyla boy ile servi; dudak ile gonca arasında ilgi kurulmaktadır. Burada "Serviyi mi yürütmediler, goncayı mı konuşturmadılar." yani iki işi de yaptılar anlamı da mevcuttur.

Servisüň bāgçelerde șalın ey serv-i çemān

Sen șalındıkç̧a çemen pāyına olsun rû-māl. ${ }^{24}$

"Ey çimenliklerin servisi (sevgili) sen servisin, bahçelerde salınarak gez; sen salındıkça da çimen ayağının altında yayılıp gitsin."

Câzim adlı şairin bu beytinde harika bir kır manzarası ve kırlarda, çimenler üzerinde yürüyen sevgili hayali mevcuttur.

Halîlî, sevgilinin boyundan bahsederken servi boylunun ayağının altındaki toprak olmak istediğini belirtmektedir. Divan şiirinde açıkça bilinen bir gerçektir ki bu durum aslında sevgiliye yakın olmanın bir yoludur ve âşık için en büyük mutluluktur.

Yine dil virdigim bir āf-tāb-ı 'ālem-ārādır

Yolunda pāy-māli oldığım bir serv-i bālādır. ${ }^{25}$

"Yine gönlümü kaptırdığım âlemi aydınlatan bir güneştir; yolunda çiğnenmiş olduğum da yine bir uzun boylu servidir."

Nahifî Efendi "cân" kelimesinin içindeki elif olarak gördüğü serviyi, yani sevgilinin boyunu, her şeyi feda edecek kadar değerli bulmaktadır:

Beni cān gibi teşrîf-i ḳudûmı eylesün iḥyā

Helāk oldum o serviñ yoluna cānlar fedā gelsün. ${ }^{26}$

“Beni, o sevgilinin cân kelimesindeki elif gibi olan boyuyla gelmesi ve ayağını bulunduğum yere basması canlandırsın. Böylece o servinin yoluna helâk olan cânlarım feda olsun." Bu beyitte servi elife benzetilmekte ve o harf olmadan "cân" kelimesi (جان) yazılamamaktadır; yani sevgilinin olmadığ 1 yerde canın bir anlamı yoktur.

Servi ile gül ilişkisi, hem gül ile bülbül aşkından hem de mezarlıklarda servilerin altına gül dikilmesinden mülhemdir. Meşhur gül-bülbül hikâyesinde servi, bülbülün arabulucusu olmuştur. "Eskiden

24 Hakverdioğlu, Damat İbrahim Paşa İçin Yazılan Lâle Devri Kasideleri, s. 358, beyit 23.

25 Hakverdioğlu, Damat İbrahim Paşa İçin Yazılan Lâle Devri Kasideleri, s. 787, beyit 20.

26 Hakverdioğlu, Damat İbrahim Paşa İçin Yazılan Lâle Devri Kasideleri, s. 200, beyit 3. 
servi ağaçlarının dibine gül fidanı dikerler ve dallarını servinin gövdesine doğru gelecek şekilde uzatırlardı. Güller açtığında servi adeta bir gül ağacına döner ve bakanların içini ferahlatacak bir görünüm arz ederdi." ${ }^{27}$ Halkımız da adeta bu ilişkiyi perçinlemek ister gibi serviler altına güller dikmişlerdir. Ebu'l- Es'ad Efendi:

Şaḳāyıḳ-rûy-1 maḥbûbān açıldı gül-şene şimdi

Șalunsunlar miŝāl-i serv kim vaḳt-i temāşādir. ${ }^{28}$

"Pembe yüzlü sevgililer gül bahçesine çıktılar, şimdi temaşa, seyir, gezinti zamanıdır, servi gibi salınsınlar." diyerek bu güller içindeki servileri anlatmaktadır.

\section{8- Servi Huzur Verendir}

Sâmî Efendi, servinin etrafa verdiği ferahlığı, onu etrafı gamdan süpüren bir güzele benzeterek vurgulamaktadır.

Yine her serv-i sehî destine cā-rûb almış

Sāha-i hāạtır-i pür-ġamdan ider def'-i gubār. ${ }^{29}$

"Yine fidan gibi dosdoğru servi eline süpürge almış, gamla dolu hatıralardan gamı, kederi def eder."

Bu huzuru lâle yanaklı güzeller de Şerîf'in beytinde fark eder:

Rûzgār ile 'aceb buldı șuyın serv-i sehî

Ṭurmayup sāyesine lāle 'izāāān getürür. ${ }^{30}$

"Uzun boylu servi acayiptir ki zamanla suyunu buldu; bu yüzden durmadan gölgesine lâle yanaklıları getirir." Güzeller onun altında eğlenmeye gelirler.

\section{9- Servi Yol Boyu Dizilen Güzellerdir}

Lâle Devri şâiri olması hasebiyle Necîb, güller, serviler, fidanlar dolu bu beytinde yol boyu dizilen servilerden bahis açmaktadır:

Döşendi reh-güzārı rîk-i ezhārıyla gül-zārıñ

Selāma turdı serv ile nihālānı ḩıyābānıñ. ${ }^{31}$

"Gül bahçesinin hoş çiçeklerle etrafı döşendi; servi ve servinin fidanları iki taraflı yol boyu selama durdular." Böylece, Lâle Devrinin hayat anlayışını yansıtan bir ifade ortaya çıkmıştır.

Atilla Şentürk, Osmanlı Şiiri Antolojisi, Yapı-Kredi Yayınları, İstanbul, 1999, s. 189.

28 Hakverdioğlu, Damat İbrahim Paşa İçin Yazılan Lâle Devri Kasideleri, s. 257, beyit 18.

29 Hakverdioğlu, Damat İbrahim Paşa İçin Yazılan Lâle Devri Kasideleri, s. 382, beyit 13.

30 Hakverdioğlu, Damat İbrahim Paşa İçin Yazılan Lâle Devri Kasideleri, s. 399, beyit 3.

31 Hakverdioğlu, Damat İbrahim Paşa İçin Yazılan Lâle Devri Kasideleri, s. 443, beyit 11. 


\section{0- Yeșil Libaslıdır}

Hemān bir dil-ber-i bî-miŝl ü bî-hem-tā ḳıyās eyler

Görenler cāme-i sebzin ile serv-i h̆ırāmānı. ${ }^{32}$

“Ey sevgili görenler senin benzersiz yeşil elbisen ile salınan serviyi kıyas ederler."

Kâzım, bu beytinde servinin her dem yeşil olmasını sevgilinin elbisesine benzetmektedir. Tabiidir ki sevgilinin elbisesi, yeşilin en kıyas kabul edilmezine sahiptir.

Yine, servinin yeşil elbisesini öne çıaran 'Azîm' in beyti:

Yeşillendi dırahtān ser-te-ser bu sāl-i hürremde

Kuruldı bir zümürrüd sāye-bān serv-i çemān üzre. ${ }^{33}$

"Bu mutlu yılda da baştan başa ağaçlar yeşillendi; bu arada çimenin servisi üzerine zümrüt yeşili bir çadır kuruldu."

Beyitte servi, yeşil bir çadır görüntüsü vermektedir.

\section{1- Servi Kumruyu Kendine Âşık Edendir}

Lâle Devri'nin en ünlü siması Nedîm de kumru-servi alakasını beytine konu etmiştir:

İdüp bayraḳ-firāz-1 nîzede pîçîde şehbālin

Güşād itdi perin ḳumrı ser-i serv-i çemān üzre. ${ }^{34}$

$\mathrm{Bu}$ beyitte servinin mızrağa, kumrunun kanadının ise bayrağa benzetildiği renkli bir imge ortaya çıkmıştır.

"Kumru, en uzun tüyünü kıvırarak, mızrak ucunda bayrak kaldırmış gibi çemende servinin üzerinde kanadını açtı."

Ebu'l- Es'ad, kumru-servi ilişkisini bir gözlemini ekleyerek şöyle anlatmaktadır:

Sürüp dāmān-1 serve rûy ḳumrı nitdigün bilmez

Ki țavḳın pāyına ḥālḥāl itmiş bir temāşādır. ${ }^{35}$

"Servinin eteğine yüzünü süren kumru ne yaptığını bilmez; çünkü gerdanlığını ayağına halhal, zincir etmiş gibi garip bir görünüştedir." Kumruların boynunda bulunan tasma, gerdanlık, ziynet benzeri tüyler halhala, zincire benzetilmektedir ve bu zincir kumruyu serviye bağlamaktadır. Kumrunun bu hâli sevinçten ne yaptığını bilmemek olarak düşünülmelidir; çünkü sevgilisine yaklaşmıştır.

32 Hakverdioğlu, Damat İbrahim Paşa İçin Yazılan Lâle Devri Kasideleri, s. 473, beyit 12.

33 Hakverdioğlu, Damat İbrahim Paşa İçin Yazılan Lâle Devri Kasideleri, s. 526, beyit 2.

34 Hakverdioğlu, Damat İbrahim Paşa İçin Yazılan Lâle Devri Kasideleri, s. 206, beyit 7.

35 Hakverdioğlu, Damat İbrahim Paşa İçin Yazılan Lâle Devri Kasideleri, s. 258, beyit 25. 
Kumru-servi ilişkisini ele alan bir başka beyit, Feyzî'den:

Olur ḳumrı-yı dil-efkār-1 zülf-i yār ile bende

Riyāż-1 'ālem içre ḳadd-i dil-ber serv-i bālādır. ${ }^{36}$

"Dünya bahçesi içinde sevgili bir uzun boylu servi; âşı̆̆ı da yârin zülfü ile bağlanmış, yaralı gönüllü kumru olur." Kumrunun bağı, yukarıda bahsettiğimiz gerdanındaki zincire benzeyen tüyleridir.

\section{2- 'Ar' ar ile İlişkilidir}

Mâdih Efendi, gül bahçesindeki servileri sıra sıra dizilmiş teşrifatçılara benzetmektedir:

Bulundı ḳaydı teşrîfāt-ı gülde serv-i āzādıñ

Anıñ çün țutdılar 'ar'arla anı şimdi hem-pāya. ${ }^{37}$

"Gülü karşılayanlar listesinde servinin de kaydı bulunduğu için onu, şimdi arar ağacı ile bir tuttular." Bu beyitte; gülün çimenlik yerde, kırlarda serbestçe gezdiği bir anda yanında servinin bulunması, onun dağ servisi olarak bilinen ve bir anlamda sosyal hayattan uzak kalan arar ağacı ile aynı listeye yazılmasına neden olmuştur, denilmektedir.

\section{3- Salınan Sevgilidir}

'İzzet, bu beytinde sevgiliyi servi olarak betimlemektedir.

Nāz ile serv-i sehîler sû-be-sû șalınmada

Bir ser-āmed-i dil-ber-i şîrîn ü müsteŝnā gibi. ${ }^{38}$

"Dümdüz serviler her yerde müstesna, baş tacı edilen, şirin dilberler gibi salınmakta."

Şehdî ise sevgilinin tavrını, işvesini şöyle dile getirmektedir:

Kabā-yı sebz ile güyā ki hûura-i behiştîdir

Hurām eyledi nāz u nahvet ile serv-i āzādı. ${ }^{39}$

"Sevgilinin servi boyu, naz ve gurur ile salındı; bu hali ile o, yeşil kaftanı ile sanki cennetin hurisidir."

Ebu'l- Es'âd, konumuz ile ilgili en güzel ifadelerden birini bu beyitte yakalamıştır:

Ebu'l-Es'ād serve söyle ġarrālanmasun ġayrı

Nihāl-i ḳadd-i hûub-1 dil-rübā a'lādan a'lādır. ${ }^{40}$

36 Hakverdioğlu, Damat İbrahim Paşa İçin Yazılan Lâle Devri Kasideleri, s. 170, beyit 34 .

37 Hakverdioğlu, Damat İbrahim Paşa İçin Yazılan Lâle Devri Kasideleri, s. 191, beyit 7.

38 Hakverdioğlu, Damat İbrahim Paşa İçin Yazılan Lâle Devri Kasideleri, s. 576, beyit 11.

39 Hakverdioğlu, Damat İbrahim Paşa İçin Yazılan Lâle Devri Kasideleri, s. 195, beyit 9.

40 Hakverdioğlu, Damat İbrahim Paşa İçin Yazılan Lâle Devri Kasideleri, s. 261, beyit 74 . 
“Ey Ebu'l-Es'âd serviye söyle kendisini güzel görüp durmasın artık; çünkü gönül alan güzelin (sevgilinin) fidan boyu yüceden de yücedir."

\section{Sonuç}

Nedîm'in meşhur şiirinde Sa'dâbâd'a götürdügü serv-i revân, divan şiirinin en narin ağacı olarak sevgiliye boy pos olmayı hak etmiştir.

Bir safa bahşedelim gel şu dil-i nā-şāda

Gidelim serv-i revānım yürü Sa'dābād'a

İşte üç çifte kayık iskelede āmāde

Gidelim serv-i revānım yürü Sa'dābād'a. ${ }^{41}$

Yukarıda saydığımız özellikleri ve beyitlerde örneklendirdiğimiz zengin çağrışımları ile bu ağaç, divan şiirinde haklı bir yere sahip olmuştur. Sevgili neden servi boyludur, sorusunun cevabi bu ağacin özellikleri araştırıldıkça daha da iyi anlaşılacaktır. Divan şairleri, hiçbir benzetmeyi tek bir nedene bağlı olarak kullanmamıştır; hele ki bu tüm divan şiirinde kullanılan bir mazmun olmuşsa. Bu konuda kullandığımız Mecmu'a da lâle konusunda olduğu gibi servi hususunda da oldukça zengin bir kaynaktır. Faiz Efendi ve Şakir Bey tarafından toplanan bu şiirler, Nevşehirli Damat İbrahim Paşa'ya ve bir miktar da III. Ahmed'e sunulan kasideleri ihtiva etmektedir. Lâle Devri şairlerinin servi ile ilgili hayal güçlerinin bir kısmını böylece gözler önüne sermiş ve servinin haklı bir şöhrete sahip olduğunu ortaya koymuş olduk. Bu şöhretin kaynağı olan ve yukarıda sayılan yirmi bir özelliğin her birinin ayrı ayrı divan şairi tarafında gözlemlenip gözlemlenmediği hususu ayrı bir merak ve inceleme konusudur. Özellikle yirminci maddede kaydedilen, servi ağacının dalları ile Allah kelamının Arapça yazımı arasındaki benzerliğin, divan şairi tarafından da biliniyor olması, bu şairler tarafından tabiatın gerçekten kılı kırk yararcasına, ayrıntılarıyla gözlemlendiğini göstermektedir.

41 Muhsin Macit, Nedim Divanı, Akçağ, Ankara, 1997, s. 264. 
230 | Metin HAKVERDİOĞLU

\section{Kaynakça}

Akyüz, Kenan ve diğerleri, Fuzîlî Divânı, Akçağ, Ankara, 2000.

Bayram, Yavuz, "Servi", Türk Dünyası Edebiyat Kavramlarn ve Terimleri

Ansiklopedik Sözlüğ̈̈, c. 5, Atatürk Kültür Merkezi Başkanlığ

Yayınları, Ankara, 2006.

Çavuşoğlu, Mehmet, Necati Bey Divanının Tahlili, Kitabevi Yayınları, İstanbul, 2001.

Hakverdioğlu, Metin, Damat İbrahim Paşa İçin Yazılan Lâle Devri Kasideleri, Sage Matbaacilik, Ankara, 2012.

Kaplan, Yunus, "Divan Şiirinde Ölüm Karşısında Âşıkların İstekleri”,

Turkish Studies-International Periodical for the Languages,

Literature and History of Turkish or Turkic, c. 5, say1: 3, 2010.

Levend, Agah Sirrı, Divân Edebiyatı-Kelimeler ve Remizler-Mazmunlar ve Mefhumlar, Enderun Kitabevi, İstanbul, 1984.

Macit, Muhsin, Nedîm Divânı, Akçă̆, Ankara, 1997.

Özerden, Gülümser, Divan Şiirinde Servi (15-16. yüzyıllar), Yayınlanmamış Yüksek Lisans Tezi, Çukurova Üniversitesi Sosyal Bilimler Enstitüsü, Adana, 2015.

Pala, İskender, Ansiklopedik Divan Şiiri Sözlüğü, Kapı Yayınları, İstanbul, 2005.

Seçmen, Özcan ve diğerleri, Tohumlu Bitkiler Sistematiği, Ege Üniversitesi Basımevi, İzmir, 1998.

Sefercioğlu, M. Nejat, Nev'î Divanının Tahlili, Kültür Bakanlığı Yayınları, Ankara, 2001.

Şentürk, Atilla, Osmanlı Şiiri Antolojisi, Yapı-Kredi Yayınları, İstanbul, 1999.

Tanpınar, Ahmet Hamdi, 19. Asır Türk Edebiyatı Tarihi, Çağlayan Kitabevi, İstanbul, 2001.

Tarlan, Ali Nihat, Fuzulî Divânı Şerhi, AKÇAĞ, Ankara, 1998.

Tarlan, Ali Nihat, Necati Bey Divânı, MEB Yayınları, İstanbul, 1997.

Tolasa, Harun, Ahmet Paşa'nın Şiir Dünyası, Akçă̆ Yayınları, Ankara, 2001. 